\title{
Early Diagnostics and Prevention of Osteoporosis in Women in Pre- and Postmenopausal Period
}

\author{
Abdieva M. O. \\ Department of Gynecology and Obstetrics, Tashkent city, Tashkent Medical Academy
}

\begin{abstract}
Purpose: To improve the early diagnosis and prevention of osteoporosis and its complications in women pre - and postmenopausal women using the most informative biochemical, radiological, clinical and anamnestic tests. Materials and Method: 49 women at the age of 45-65 years are examined within the bounds of aroutine inspection. The examinationwas carried out by the method of dual-energy X-ray absorptiometry in three points of theskeleton (the lumbar part of backbone L1-L4, the proximal part of thefemur and thedistal part of forearm) by means of device QDR-4500 Elite of firm Hologic, USA. The marker of bone resorbtion (B-CrossLaps), the marker of bone formation (osteocalcin) and parathyroid hormone in blood serum of each woman were measured on the Humolazer automated analyzer (German). The most expressed disorders of bone density in women of pre-and postmenopausal ages were accompanied by increase of levels B-CrossLaps, osteocalcin and parathyroid hormone in blood serum. Results: Using standard indicators, from 0,162 to $0,436 \mathrm{ng} / \mathrm{ml}$ for osteocalcin - 11 to $32 \mathrm{ng} / \mathrm{ml}$, of all examined women were divided into three groups. The first group included 15 patients with normal markers of bone metabolism, the second 16 women with normal levels of osteocalcin and increased numbers B-CrossLaps, and the third included 18 women with elevated levels of both indicators. B-CrossLaps is the most sensitive biochemical marker of adecrease in bone density; this marker precedes increase of osteocalcin level and occurrence of densimetric signs of osteoporosis. On the basis of biochemical markers of bone turnover (B-CrossLaps and osteocalcin) and estimation of clinical-anamnestic risk factors, as well as being based on results of densitometry, the algorithm of early diagnostics and prevention of osteoporosis in the women of pre- and postmenopausal ages is developed. Conclusion: The most pronounced disorders of bone density in women pre - and postmenopausal age is accompanied by increased levels of B-CrossLaps, osteocalcin and parathyroid hormone in the serum. B-CrossLaps is the most sensitive biochemical marker of lower bone density prior to the increase in the content of osteocalcin and the appearance of densitometric evidence of osteoporosis.
\end{abstract}

Keywords: osteoporosis in pre- and postmenopausal women, early diagnostics, prophylaxis

\section{Introduction}

Osteoporosis in women pre - and postmenopausal period is relevant, which is determined by its high prevalence, multifactorial nature, the common disability.

The prevalence of osteoporosis in women depends primarily on theage of patients, and may also vary depending on the region of residence [1]. The development of osteoporosis is particularly true for women to pre - and postmenopausal age. The probability of their formation depends on the duration of menopause, menopausal syndrome symptoms, frequency and severity of stress reactions, unfavorable heredity [2, 3]. It is known that one of the major pathogenic factors determining the decrease in bone density is hypoestrogenia characteristic of women pre - and especially postmenopausal age [4]. However, not diminished the role of other factors that acquire their value with age in the formation of the pathological process (reduction of the formation of vitamin $\mathrm{D}$, growth hormone, insulin-like factor 1 , thegrowth of the influence of parathyroid hormone, etc.) [5]. Of particular relevance at this time becomes early detection and prevention of osteoporosis in women pre - and postmenopausal women, as well as the formation of risk groups on the basis of the most informative biochemical and clinical-anamnestic signs. It is known that widely in medicine for the early detection of osteoporosis is used densitometric study. However, are the most sensitive biochemical markers of bone resorption [6]. Their content in the blood and urine may increase even before the appearance densitometric signs of rarefaction of bone tissue.
Therefore, the aim of our work was to improve the early diagnosis and prevention of osteoporosis and its complications in women pre - and postmenopausal women using the most informative biochemical, radiological, clinical and anamnestic tests $[7,8]$.

\section{Materials and Methods}

We examined 49 women aged 45 to 65 years who was a routine inspection to the clinic NDC-medic using dualenergy x-ray absorptiometry at three points of the skeleton (lumbar spine L1-L4, proximal femur, and distal forearm). Bone loss was evaluated using the apparatus QDR-4500 Elite, HologicCompany, the USA using T-test. The norm considered values, deviating by less than $1 \mathrm{SD}$; deviations from $1 \mathrm{SD}$ to $2.5 \mathrm{SD}$ regarded as osteopenia; deviation of more than $2.5 \mathrm{SD}$ osteoporosis.

Determining the level of amarker of bone resorption (BCrossLaps), the level of amarker of bone formation (osteocalcin) and parathyroid hormone was performed on an automatic analyzer Humolazer (Germany) using test systems "Elecsys B-Cross-laps-serum", "Elecsys N-MIDosteocalcin" and a set of reagents "Elecsys-PTH" with monoclonal antibodies. The content (in $\mathrm{ng} / \mathrm{ml}$ or PG/ml) was carried out using a calibration curve obtained with a special device for this method of calibration is two-point, and the reference calibration curve obtained from the barcode of the reagent.

Statistical analyses were carried out using the programs Excel and parametric statistical methods. 


\section{International Journal of Science and Research (IJSR) \\ ISSN (Online): 2319-7064}

Index Copernicus Value (2013): 6.14 | Impact Factor (2014): 5.611

\section{Results and Discussion}

When analyzing the levels of biochemical markers of bone metabolism (osteocalcin and CrossLaps) in women aged 45 years and above was collected from heterogeneity. Using standard indicators (for B-CrossLaps from 0,162 to 0,436 $\mathrm{ng} / \mathrm{ml}$ for osteocalcin - 11 to $32 \mathrm{ng} / \mathrm{ml}$ ) of all examined women were divided into three groups. The first consisted of 15 patients with normal markers of bone metabolism, the second 16 women with normal levels of osteocalcin and increased numbers B-CrossLaps, and the third consisted of 18 female with elevated levels of both indicators. All patients with elevated levels of at least one of the markers of bone remodeling were "high sharing", which is traditionally a high-risk group in terms of the formation of osteoporosis.
As can be seen from thetable, women of the third group the average age were significantly higher than in the first group and did not differ from the age of the patients of the second group. The average level of B-CrossLaps was highest in the third group, 1.6 times less than a second and 2.1 times less in the first group $(p<0.001)$. Draws the attention of the higher average level of In-CrossLaps in patients with higher rates of osteocalcin, compared with patients of the second group, which had normal numbers ( $<<0.001$ ). A similar regularity is observed in the groups in the average levels of osteocalcin: maximum rate determined in women in the third group, 1.6 times less in the second, in 2,1 times less than in the first $(p<0.001)$. It should be noted that, despite the presence of normal levels of osteocalcin, its average value in women of the second group was significantly higher than in patients of the first group $(p<0.001)$. Comparative characteristics of laboratory and densitometric parameters in the examined women.

\begin{tabular}{|c|c|c|c|c|c|c|c|c|}
\hline \multirow[t]{3}{*}{ No } & \multirow[t]{3}{*}{ Groups of patients } & \multirow[t]{3}{*}{$\mathrm{N}$} & \multirow{3}{*}{$\begin{array}{c}\text { Ages } \\
M \pm \text { m year }\end{array}$} & \multicolumn{3}{|c|}{ Results of laboratory tests } & \multirow{2}{*}{\multicolumn{2}{|c|}{$\begin{array}{l}\text { A decrease in bone } \\
\text { density (bone } \\
\text { densitometry) }\end{array}$}} \\
\hline & & & & \multirow{2}{*}{$\begin{array}{l}\text { B-CrossLabs } \\
\mathrm{M} \pm \mathrm{m} \text { нг/мл. }\end{array}$} & \multirow{2}{*}{$\begin{array}{c}\text { Osteocalcin } \\
\mathrm{M} \pm \mathrm{m} \mathrm{нг/мЛ.}\end{array}$} & \multirow{2}{*}{$\begin{array}{l}\text { Parathyroid hormone } \\
\qquad \mathrm{M} \pm \mathrm{m} \mathrm{pmol} / 1\end{array}$} & & \\
\hline & & & & & & & Abs & $\mathrm{M} \pm \mathrm{m} \%$ \\
\hline 1 & $\begin{array}{l}\text { B-CrossLabs in normal } \\
\text { Osteocalcin in normal }\end{array}$ & 15 & $53,20 \pm 1,20$ & $0,37 \pm 0,05$ & $21,14 \pm 1,02$ & $56,95 \pm 3,52$ & 15 & $53,50 \pm 9,40$ \\
\hline 2 & $\begin{array}{c}\text { B-CrossLabs above normal } \\
\text { Osteocalcin in normal }\end{array}$ & 16 & $55,50 \pm 0,90$ & $0,49 \pm 0,02$ & $27,89 \pm 0,79$ & $56,74 \pm 2,68$ & 16 & $53,30 \pm 9,10$ \\
\hline 3 & $\begin{array}{c}\text { B-CrossLabs above normal } \\
\text { Остеокальцинаbove normal }\end{array}$ & 18 & $57,20 \pm 1,00$ & $0,77 \pm 0,05$ & $44,71 \pm 1,42$ & $71,82 \pm 4,90$ & 25 & $80,60 \pm 7,00$ \\
\hline & $\begin{array}{c}\text { The reliability of differences } \\
\text { between groups }\end{array}$ & & p1-3* & $\begin{array}{l}\text { p1-2**** } \\
\text { p1-3*** } \\
\text { p2-3*** }\end{array}$ & $\begin{array}{l}\text { p1-2*** } \\
\text { p1-3*** } \\
\text { p2-3*** }\end{array}$ & $\begin{array}{l}\text { p1-3* } \\
\text { p2-3** }\end{array}$ & & $\begin{array}{l}\text { p1-3* } \\
\text { p2-3* }\end{array}$ \\
\hline
\end{tabular}

The average level of parathyroid hormone was maximum in women with advanced In-CrossLaps and osteocalcin, was significantly lower in the second and first groups $(\mathrm{p}<0.01$ and 0.05 ). Violation of bone density more often than in other groups was observed in women with a simultaneous increase in B-CrossLaps and osteocalcin (80.6\% of cases). In the second and first groups indicated a pathological process was detected with equal frequency and was approximately $53 \%$.

Thus, the "high exchange" on the probability of formation of osteoporosis in women pre - and postmenopausal women mixed. The highest frequency of the decrease in mineral density of bone tissue in the examined patients correlated with elevated levels of a marker of bone resorption and bone formation that characterizes the maximum voltage of the above-interrelated processes involved in the remodeling of bone [8-12]. In the group with isolated increase In CrossLaps and with normal parameters in both markers of bone metabolism, the rate of abnormal bone density was about the same. Therefore, the increase in the level of BCrossLaps, probably the first and most sensitive indicator of decreased balance in the remodeling of bone in the resorption [13-16], which however does not always imply the emergence of densitometric evidence of a decline in its density [17]. Increased levels of osteocalcin can be probably regarded as one of the compensatory reactions from the side of the mechanisms of bone formation, which is connected with more severe levels of bone resorption. With this combination, we have already observed in a large percentage of cases, the changes of densitometric indices of density. It can be assumed that the increased level of parathormone in the third group along with hypoestrogenia is one of the mechanisms reducing bone density [18]. Patients with isolated increase In CrossLaps (the second group) or normal rates of the markers (the first group) it is necessary to assess for the presence of clinical and anamnestic risk factors. The most importantthings are unfavorable heredity, the presence of menopause (especially longer than 10 years) and symptoms of climacteric syndrome, frequent and severe stress reactions in the anamnesis, clinical manifestations of hypoestrogenism in the genitourinary system (for example, atrophic vaginitis with the presence or absence of colpocleisis), operative intervention in history regarding the omission of the vaginal walls, as well as adnexectomy (especially bilateral), taking medications that contribute to osteoporosis [19-25].

\section{Conclusion}

1) The most pronounced disorders of bone density in women pre - and postmenopausal age is accompanied by increased levels of B-CrossLabs, osteocalcin and parathyroid hormone in the serum.

2) B-CrossLaps is the most sensitive biochemical marker of lower bone density prior to the increase in the content of osteocalcin and the appearance of densitometric evidence of osteoporosis.

3) Biochemical markers of bone metabolism (osteocalcin and CrossLabs), clinical-anamnestic risk factors, as well as results of densitometry on the basis of the algorithm of 


\section{International Journal of Science and Research (IJSR) \\ ISSN (Online): 2319-7064}

Index Copernicus Value (2013): 6.14 | Impact Factor (2014): 5.611

early diagnostics and prevention of osteoporosis in women, pre - and postmenopausal age.

\section{References}

[1] Benevolenska L. I. Bisphosphonates in the treatment and prevention of osteoporosis / L. I., Benevolenska, Ross. Rheumatology. - 1998.- No. 2.-P. 2-9.

[2] Benevolenska, L. I. the General principles of prevention and treatment of osteoporosis / L. I., Benevolenska // Consilium. - 2000. - Vol. 2, No. 6. - S. 1-6.

[3] Dushenkov T. A. Diagnosis and prevention of osteoporosis and its complications in postmenopausal women: author. dis. candidate. honey. Sciences. $\mathrm{SPb} ., 2005 .-18 \mathrm{~S}$.

[4] Ermakova I. P. Biochemical markers of bone tissue metabolism and their clinical use / Ermakova I. P. // Journal "Laboratory". — 2001. — № 1. - S. 3-5.

[5] Zasursky I. E. Osteoporosis and reproductive system of women: the methodical grant for students, medical interns, clinical residents Niiig, medical University / I. E. Zazersky, D. A. Niauri, Emanuel V. L. [and others]. - SPb.: SOTIS, 1998. - 46.

[6] Nasonov E. L. Osteoporosis: standards for diagnosis and treatment / E. L. Nasonov // Consilium. — 2001. Vol. 3, No. 9. - S. 1-10.

[7] Osteoporosis (etiology, diagnosis, treatment): per. $\mathrm{S}$ angl.ed L. Riggs, L. J. M. Melton. - SPb.: CJSC "Publishing house BINOM", "Nevsky dialect", 2000.$560 \mathrm{p}$

[8] Shapovalenko S. A. the use of the drug Calcium D3 Nycomed for the prevention of steroid osteoporosis in women with early menopause / Shapovalenko S. A. // Osteoporosis and osteopenia. - 1999. - No. 1. - P. 46-48.

[9] Endocrinology: Management: per. s angl. / Red. N. Lavigne

[10]Christiansen C. Prediction of rapid bone loss in postmenopausal women / C. Christiansen, B. Riis, P. Roedro // Lancet. - 1987. - Vol. 1(8542). - P. 1105-1108.

[11] Delmas P.D. Biochemical markers of bone turnover in osteoporosis / P.D. Delmas // Osteoporosis: etiology, diagnosis and management / eds. Riggs B.L., Metton L.J. — N.-Y.: Raven Press, 1988. - 297 p.

[12] Delmas P.D. For the Committee of Scientific Advisors of the International Osteoporosis Foundation. The use of biochemical markers of bone turnover in osteoporosis / P.D. Delmas, R. Eastell, P. Garnero [et al.] // Osteoporosis International. - 2000. - Vol. 6. - P. 217.

[13] Heaney R.P. Calcium, dairy products and osteoporosis / R.P. Heaney // J. of the American College of Nutrition. - 2000. - Vol. 19, № 2. - P. 83-99.

[14] Johnell O. Age and set patterns of hip fractures: changes in 30 years / O. Johnell, B. Nilsson, K.J. Obrant [et al.] // ActaOrthop. Scand. — 1984. — Vol. 55. - P. 290292.

[15]Lindsay R. Estrogen treatment of patients with established postmenopausal osteoporosis / R. Lindsay, J. Tohme // Obstet. Gynecol. — 1990. — Vol. 76. — P. 290-295.
[16] Looker A.C. Clinical use of biochemical markers of bone remodeling: current status and future direction / A.C. Looker, D.C. Bauer, C.H. Chesnut [et al.] // Osteoporosis Int. - 2000. - Vol. 11, № 6. - P. 467480.

[17] Manolagas S.C. Birth and death of bone cells: basic regulatorymechanisms and implications for the pathogenesis and treatment of osteoporosis / S.C. Manolagas // Endocr. Rev. - 2000. - Vol. 21, № 2. - P. 115-37.

[18] Morrison N.A. Prediction of bone density from vitamin Dreceptor alleles / N.A. Morrison, J.L. Qi, A. Tokata [et al.] // Nature. - 1994. - Vol. 367. - P. 284-287.

[19]Plosker G.L. Intranasal Salkatonin (salmon calcitonin): a reviewof its pharmacological properties and role in the management of postmenopausal osteoporosis / G.L. Plosker, D. VcTavish // J. Drug. Aging. - 1996. — Vol. 8, № 5. - P. 378-400.

[20] Puins S.H. The role of quantitative ultrasound in the assessmentof bone: a revive / S.H. Puins, H.L. Jorgensen, L.V. Jorgensen [et al.] // Clinical Physiology. — 1998. — Vol. 18, № 1. - P. 3-17.21.

[21] Ristelli J. Radioimmunoassay for the pyridinoline crosslinked carboxy-terminal telopeptide type 1 collagen: a new serummarker of bone collagen degradation / J. Ristelli, I. Elornaa,S. Niemi [et al.] // Clin. Chem. 1993. - Vol. 39. - P. 635-640.

[22] Sinaki M. A new back support in therehabilitation of osteoporosisprogram-exercise: posture training support / M. Sinaki // Osteoporosis / eds. C. C hristiansen, K. O vergaard. - Copenhagen: OsteopressApS, 1990. Vol. 3. - P. 1355-1357.

[23] Sinaki M. Bone mineral content: relationship to muscle strengthin normal subjects / M. Sinaki, J.L. Opitz, H.W. Wahner // Arch. Phys. Med. Rehabil. - 1974. - Vol. 55 - P. 508-512.

[24] Udoff L. Combined continuous hormone replacement therapy: a critical revive / L. Udoff, P. Langenberg, E. Adachi // Obstet. Gynecol. — 1995. — Vol. 86, № 2. - P. 306-316.

[25] World Health Organisation. Assessment of Fracture Risk andits Application to Screening for Postmenopausal Osteoporosis. WHO Technical Report. - Series 843. - Geneva: WHO, 1994. 